\title{
The Allurement of Ethnonationalism in Nigerian Politics The Contemporary Debate
}

\author{
E. IKE UDOGU*
}

\section{Introduction}

I

T IS SAFE TO contend that many individuals might not consider it insulting to be referred to as ethnonationalists, because the concept generally implies the love for one's ethnic group (e.g., Mandingo, Jewish, Serbian, Yoruba, Zulu, Russian, etc). Yet, there is often a hidden problem stemming from the psychological and primordial attachment to one's ethnic group in a pluralistic society. The situation, in a polity, such as Nigeria, becomes more problematic when the politics of who gets what, when, and how gravitate toward ethnic clashes and antagonisms. To this end, this study seeks to do the following: 1. examine briefly the revival of the issue of ethnonationalism in Nigerian politics in light of the contemporary debate on state formation; 2. suggest possible ways to ameliorate and mitigate the centrifugal tendencies of ethnonationalism in the republic.

Generally, the assumption has always been that an adequate education was likely to induce the various collectivities to peel off or at least modify their ethnic identities - a move that could result in the superimposition of nationstate nationalism upon ethnic loyalties. In other words, theoretically, education would retard and weaken the noncentripetal dimensions of ethnicity. There might be some truth to this thesis, since many of those who have been in the vanguard in opposition to ethnic politics have traditionally come from the educated cadres. But, there are also many in this group who have, in the struggle for power, resurrected their ethnic emblems and solidarity, as rallying cries in the competition for the authoritative allocation of values.

Probably, it was that sense of an innate ethnic unity in different groups that prompted N. Kofele Kale to contend, inter alia, that: 1. attachment to ethnic group values - by so-called tribesmen - holds true for the majority of people living in polyethnic societies and 2. these values are held onto by an ethnic man [or person] regardless of environmental variations (education, job or position);

* Department of Political Science, Francis Marion University, Florence, South Carolina, U.S.A. 
i.e., an ethnic [person] remains ethnic whether domiciled in a rural village or in an urban center. ${ }^{1}$ For example, Ebino Babatope, minister of Transport and Aviation, in the Abacha administration, in an interview with The Sentinel said: "... And if people think that because I am a minister that I have forgotten the fact that one, I'm an Ileshaman, two, I'm an Ijeshaman, and third, I'm a Yorubaman, then fourth, I am a Nigerian citizen, then such people should really go and examine themselves. I cannot divorce myself from the yearning and aspirations of the people of my roots."'2

As Alvin Rabushka and Kenneth A. Shepsle have argued, the political equation becomes more confounding and discordant in democratic and pluralistic societies. They have noted that a sense of communal solidarity tends to intensify ethnic preference, so much so, that, in the struggle for political power, to promise less for one's group in the name of harmony and accommodation was tantamount to betraying that group's interest. ${ }^{3}$ Little wonder, then, that Umaru Dikko, an influential minister in the Second Republic of Nigeria, was alleged to have expressed, proverbially, his concern regarding the inauguration of a National Conference by the Abacha administration-a conference intended to work out the modalities for the formation of Nigeria's nation-state. He said: "No man becomes a hero by selling his father's house to buy a land."4 What Dikko was implying, it has been contended, was that Abacha (a northerner) was, by the nature or scope of the National Conference that he had set up, selling off the northern interests without being cognizant of what he would get in return for the north. This assertion, attributed to Dikko, was later refuted ${ }^{5}$ But the moral of the proverb is applicable to many ethnic groups in the politics of pluralistic societies. In a real sense, the foregoing discussion was intended to provide the springboard from which to examine the serious and possible rationale for the perennial and resurgent debates on the quest to balkanize Nigeria into ethnic states. This was a view articulated in a written statement entitled "Memorandum on the proposal for restructuring Nigeria by the Ethnic Minority Rights Organization of Africa" (EMIROAF). ${ }^{6}$

\section{Ethnicity: A Conceptual Overview}

What is ethnicity? Okwudiba Nnoli provides the following definitional and interactive characteristics of ethnicity, especially in the African case:

First, it is a social phenomenon inherent in the various forms of interactions between and among members of different ethnic cleavages. Ethnic groups are social formations distinguished by the communal nature of their boundaries. The pertinent communal factor may be language, culture, or both. In the African continent, language has a tendency to be a significant defining factor. Let it suffice to say, however, that as social formations, ethnic collectivities are not necessarily homogeneous entities, even linguistically and culturally. Additionally, relations between ethnic groups in a political system tend to heighten and produce ethnicity. 
Second, much more than ethnocentrism, ethnicity is characterized by a common consciousness of being one in relation to the other relevant ethnic groups. This is particularly so, when one views ethnicity in ideological termsi.e., ethnicity construed to be the manner of thinking characteristic of a cleavage; and, in the African case often furthered by the ascriptive traditional African social patterns.

Third, exclusiveness is an attribute of ethnicity. Thus in the sociological lingo, ingroup-outgroup boundaries emerge and come to the fore. Consequently, acceptance and rejection on linguistic and cultural grounds characterize social relations.

In sum, conflict is a significant dimension of ethnicity, and this is where the ideology becomes problematic in endeavors toward the successful governance of most African polities (as, for example, in Nigeria, Rwanda, Burundi, Kenya, South Africa, etc). This is inevitable under conditions of inter-ethnic contestation in the politics of the authoritative allocation of values. Indeed, the tussle is aggravated by the scarcity of valuable resources, especially in political systems, where one's prestige is measured by an individual's wealth. One could only be wealthy if there are poor folks. So, the acceptance of inequality nourishes the allurement for material possession. The apprehension of being left out or behind in the struggle for economic and political power often generates divisive and destructive socioeconomic competition and behavior patterns. In some cases, the Nkhrumahist dictum, "Seek ve first the political kingdom - and the rest shall be added onto you," reigns supreme, and sharpens the in-group solidarity. Aggressive behavior, concluded Nnoli, may be used to limit competition in favor of the in-group. In such a political milieu, demonstrations, rioting, and various forms of agitation become major instruments in inter-ethnic relations and rivalry. ${ }^{7}$

\section{The Relevance of Ethnicity as an Analytical Tool}

Bernard E. Segal has contended that "although ethnicity is a far older basis of social organization than either the nation-state or systems of rank based more on classes and less on status groups, it does not lose its salience as these other forms develop around it."8

When in December 1958, the First Conference of the Peoples of Africa was convened in Accra, Gold Coast (modern Ghana), it issued a proclamation on tribalism [or ethnicity], vehemently condemning the imperialist tactics of manipulating it for the perpetuation of colonial domination. The participants at this convocation termed tribalism a vicious system which represented an ominous impediment to the achievement of African unity. The meeting, noted R.N. Ismagilova, not only called on political associations, trade unions, cultural groups and other organizations to take the appropriate steps to thwart the cankerworm of tribalism, but also called upon the governments of independent African countries to promulgate legislation aimed at combating and assuaging this phenomenon. In particular it suggested that propaganda and education be 
used to achieve this objective. ${ }^{9}$ In spite of that, however, attempts to depoliticize ethnicity have met with mixed results, but this by no means implies this goal is unattainable.

In the Nigerian case, paradoxically, many Nigerian leaders argued that the eradication of tribalism could help in mitigating the perplexing problems the country was confronted with, and yet, have done very little to mollify its effect in the politics of Nigeria. ${ }^{10}$

In fact, it is vexing that in spite of the proclamations against the "evils" of tribalism, its significance in the analysis of political behavior patterns in many polities remains salient. This is true in Nigeria and elsewhere. ${ }^{11}$

To go back to the central issue of the foregoing analysis, is ethnicity relevant in the politics of Nigeria? Put another way, could the complex political interactions in Nigeria be seen and be comprehended against the backdrop of the country's ethnic mosaic? Indeed, such a query might appear to be naive even to a casual observer of the politics in pluralistic societies. The Nigerian civil war, the carnage in Bosnia-Herzogovina and Rwanda, for example, illustrate the problematic nature of the politics of ethnonationalism. The question, though, is whether observers and scholars have placed too much emphasis on ethnicity as an independent variable, at least in the African case, in explaining the political topsy-turvy situation and the commotion on the continent.

Nnoli contends that numerous pitfalls attend any endeavor to explicate the ethnic phenomenon [and puzzle] in Africa. First, such an endeavor may succeed in keeping ethnic sentiments aflame by bringing them to the fore of the consciousness of the informed public. Second, it may arouse or generate divisive inter-ethnic controversy - since ethnicity is a very sensitive issue in national politics. ${ }^{12}$ But the question of ethnic "autonomy" in all its forms and ramifications may not wither away within a nation-state in the struggle for ethnic-groups survival. The Quebecois in Canada, and the Zulus in South Africa are two cases in point.

It is inadequate to concentrate on, or over-emphasize, the impact of ethnicity in African politics, as some scholars have argued, since there are other equally significant variables that must be noted in explaining the intricacies and complexities of African politics. In particular, some have contended that concerns should be directed to the role played by participants in the social production process. Arguably, a focus on such a process permits the scholar to discern historical epochs which could help to illuminate and clarify the trend and direction of social movements. ${ }^{13}$

Arche Mafeje has argued that tribalism is an anachronistic misnomer which tends to "blur" cross-cultural analysis by making discriminatory and resentful distinctions between Africa and other polities in the world. As a result of such a process, some scholars oversimplify, and indeed mystify and obscure, the true nature of economic and power relations among Africans and their complex interactions within the global economic system. ${ }^{14} \mathrm{~B}$. Magubane has contended that a focus on ethnicity obstructs a genuine effort to comprehend African societies, principally because it does not accentuate the ownership and 
control of the primary productive forces. ${ }^{15}$ Politically, Richard Sklar shares the view that a focus on ethnicity obscures the fact that, in Africa, ethnic movements may be encouraged and incited to action by the political "princes" who accede to power and use it to further their invididual and group interests. In a way, therefore, ethnicity becomes a mask for class privileges. ${ }^{16}$

Nnoli argues that, quite aside from the narrow focus on ethnicity, there is the whole issue of what weight should be attributed to it as an explanatory variable. The tendency is to point to ethnic discrepancies and view these antinomies as the principal ones in African societies. In Africa, "ethnic problems are readily apparent and very real. But this is only at the level of more empirical observation. Ethnic contradictions have an objective basis in the social structure of society. As an element of the ideological superstructure of society, ethnicity rests on, is functional for, and is determined by the infrastructure of society, the mode of production [and distribution]."17

\section{The Debate on the Greation of Ethnic States}

To some observers of Nigerian politics, it is perplexing that, on the "eve" of the twenty-first century, some Nigerians are suggesting the formation of states along ethnic lines to supersede the existing formation. What this implies is that the public pronouncements and constitutional engineering (as for example, the 1979 constitution) to eliminate ethnicity in the republic's politics have so far been in vain. Glearly, the primordial sentiments and attachment to ethnicity in the face of national difficulties can easily be resurrected to take on a high profile. In other words, its renaissance reflects the nature of the political milieu at a given epoch.

Historically, the debate concerning the balkanization of Nigeria into geoethnic entities is not novel. Its genesis could be traced to the amalgamation of the Northern and Southern protectorates in 1914. Indeed, there is a paradox flowing from the fact that the British, who were responsible for this arrangement, did not pursue the political unification question with enthusiasm. It was possible that some of the Nigerian political actors observing the British genre of governance may have been influenced by it. For example, Governor Sir Hugh Clifford in his address to the Nigerian Council on December 29, 1920, stated:

\footnotetext{
...It is the constant policy of the Nigerian government to maintain and support the local tribal institutions and the indigenous forms of government. ... Assuming... that the impossible were feasible - that this collection of self-contained and mutually independent Native states, separated from one another, as many of them are, by great distance, by difference of history and traditions and by ethnological, racial, tribal, political, social and religious barriers, were indeed capable of being welded into a single homogeneous nation--a deadly blow would be struck at the very root of national self-government in Nigeria which secures to cach separate people the right to maintain its identity, its individuality and its nationality... and the peculiar political and social institutions which have evolved for it by the wisdom and by the accumulated experiences of generations of its forbearers. ${ }^{18}$
}

It has been contended elsewhere that such a British stance served to fortify the Nigerian "tribal" groups' ethnic walls. ${ }^{19}$ Indeed, there is little wonder that 
the political "princes" who inherited power from the British colonial "monarchies" reaffirmed and paraphrased Governor Clifford's assertion as they jockeyed for political power before independence in 1960.

For instance, in 1948, Abubakar Tafawa Balewa, a leader of the Northern People's Congress (NPC), during one of Nigeria's constitutional conferences asserted that: "Since the amalgamation of the north and the south provinces in 1914, Nigeria had existed as one country on paper. ... It is still far from being united. Nigerian unity is only a British intention for the country." 20 Chief Obafemi Awolowo, himself a flagbearer of the Action Group (AG), wrote in 1947: "Nigeria is not a nation. It is a mere geographic expression. There are not 'Nigerians' in the same sense as there are 'English,' 'Welsh,' or 'French'. The word 'Nigerian' is merely a distinctive appellation to distinguish those who live within the boundaries of Nigeria from those who do not." 21

The political alignment pattern in the pre-and post-independence periods was ethnically based, ${ }^{22}$ and the outcome of the political competition, at least in the past thirty years (or two Republics), was determined by the solidarity of the major ethnic cleavages (Hausa-Fulani, Ibo, and Yoruba). ${ }^{23}$ So, the politics of ethnonationalsm ${ }^{24}$ in the struggle for power in Nigeria is commonplace but disturbing, because of its conflictual and contentious characteristic in the Nigerian polity.

Thus, the manifesto propounded by the Ethnic Minority Rights Organization of Africa (EMIROAF), for the creation or states on the basis of ethnic chasms, as a way out of the perpetual political crisis in the country, is perturbing against the background of Nigeria's ethno-political history. It is, therefore, on the views of this group that I now focus my following analysis.

\section{EMIROAF and Ethnic States in Nigeria}

It is somewhat contradictory that this organization should assume the acronym EMIRAOF instead of EMIRON (Ethnic Minority Rights of Nigeria). Perhaps the adoption of EMIROAF implies that the problems of ethnic minorities extended beyond Nigeria. And, given Nigeria's size and clout in the African continent, there existed the likelihood that it could serve as a framework for other nation-states in the area that are confronted with a similar imbroglio. The issue, however, is not the group's nomenclature (i.e., EMIROAF, EMIRON, etc) so much as its motives, and the republic's acceptance (or refusal) of the organization's proclamations.

The proceeding discussion is intended to highlight some of the major points made by the group about what it perceived to be the model that might resolve the country's endemic political crisis and malaise. Moreover, attempts will be made to examine these opinions to ascertain their efficacy (or lack of it) in Nigeria's political metamorphoses. In a real sense, the discussion of the group's viewpoint issues not from the viability as an adequate or inadequate option for Nigeria, but from its exponential values as the country examines itself politically. 
In its preamble, EMIROAF contends that, "it seeks to correct the faults which led to the collapse of the First Republic and to return the country from the abyss of unitarianism into which military adventurism has led it. Accordingly, it advocates a loose federation with a collegiate presidency, a parliamentary system of govenment in the federating units of the country, an army in the territorial formation, and the enthronement of true federalism in Nigeria by the equal treatment of all ethnic groups, allowing to each ethnic group the right of political self-determination, resources and environmental control."25

As scholars familiar with the politics of Nigeria know, this position is probably predicated on the frustration stemming from the problem of leadership which has eluded the republic, and the politics of the zero-sum-game, which is responsible in part for the country's instability. Such instability marginalizes the ethnic minority groups which seek a stable government on which to press for their demands. The politics of Nigeria become particularly baffling when the majority groups use their numerical strength to accede to power and to use that position to satisfy their constituencies which elected them at the seeming expense of the minority ethnic groups. This situation becomes more problematic for the minority groups who must be "punished" for not supporting the party in government. Thus, resources and amenities are often denied them just to teach them a lesson for backing the wrong political horse. Whereas this instrumentality and strategy in politics is not peculiarly or uniquely Nigerian, the very form which it takes is often blatant and impedes Nigeria's quest for political atomism.

Arguably, EMIROAF is more concerned with the apportionment of the country's natural resources than with the ethnic strata of the nation-state. This view is given credence by its contention that the organization's formula would render it impossible for any group in power to usurp the resources of any ethnic group for its own purposes. The group recommends that, "all on-shore mineral resources shall be the property of the unit in which they are found..." 26 Accordingly, as part of the political configuration in Nigeria, the following groups will form ethnic states: 1. Ijaw; 2. Yoruba; 3. Igbo; 4. Hausa-Fulani; 5. Ibibio; 6. Kanuri; 7. Edo; 8. Nupe; 9. Urhobo; 10. Tiv; and 11. Gbagyi. ${ }^{27}$

To be sure, the group addressed the institutional and structural issues of the anticipated nation-state under the rubrics of the collegiate presidency, political parties, elections, bureaucracy, revenue, education, defence, local government, police, security agencies, foreign affairs, the judiciary and movement of people, inter alia. ${ }^{28}$ The discussion of these dimensions, however, is not within the purview of this disquisition. Moreover, the above institutions and structures are secondary and peripheral, for, in a true sense, they rest on Nigeria's economic superstructure - i.e., how the republic's resources are allocated. But the bottom line is that a group must first capture political power in order to distribute the economic resources. The minority ethnic groups at this juncture in Nigerian politics are not in the position to capture power and oversee the dispensation of resources. Is there any wonder about the allure for the creation 
of ethnic states that could enable them to use their resources for geo-ethnic development?

In addition, the frustration stemming from the exploitation of oil, the country's major source of income, at the expense of the areas producing it, has made some ethnonationalists vent their anger on behalf of their groups by agitating for ethnic autonomy. A good case in point is Isaac Boro's preoccupation with the creation of a state for the Ijaw ethnic group out of the erstwhile eastern Nigeria- a clamor that reached its crescendo in the pre-civil war era (1967-1970).29 The struggle was instigated, among other factors, by the presumed marginalization of the people, and underdevelopment of the oil-rich area.

EMIROAF's opinion should be seen for what it is--an expression of the dissatisfaction flowing from the marginalization of some of the ethnic minority groups, nourished by the wanton, rampant, and endemic corruption in Nigeria, rather than political opportunism per se.

Further, the 1994 Constitutional Conference, also dubbed the Abacha Conference (because it was conceived by Abacha), intended to thrash out the modality for the republic's future operation and sustainment, has only served to sharpen the ethnic chasms in the country, as each group coalesces to pursue its ethnic interests and agendas within the nation-state. For instance, the Committee for the Defence of Human Rights (CDHR) in Nigeria noted concernedly that: "The manner [in which the] political elite, traditional rulers and the ruling class are organizing preconference along regional lines was aimed at promoting primordial sentiments. ...Such conferences as the Northern Elders Meeting [Hausa-Fulani], the Western Elders Forum [Yoruba], and the Igbo Leaders Forum [Igbo] are not only ethnically oriented but they are also sending dangerous signals across the country [reminiscent of the pre- and post-independence alignment patterns.]"30 In previous attempts at democratic governance, such alignment patterns contributed to the political instability and angst in the country.

In light of those developments, is it not plausible to contend in the words of Colin Legum that "tribalism" was Nigeria's natural condition and was likely to remain so for a long time to come? 32 This situation is fostered and intensified by what James S. Coleman termed pan-tribal sentiment, brought about by the interaction which modernity makes possible. ${ }^{33}$

So far, the argument for the balkanization of the Nigerian polity into ethnic states has no attracted significant political disciples among a cross-section of the Nigerian political elite. This by no means implies that the issue is dead. At least, this has been the case, for the moment perhaps, because of the impracticalities inherent in the politics of contemporary Nigeria. Indeed, few have expressed this view as succinctly and emphatically as the statesman and former head of state, Olusegun Obasanjo, when he stated at the Arewa Workshop on, "State of the Nation, Which Way Forward", that:

The interwovenness and complementarity of the various aspects of our national life [in Nigeria] make a breakup totally undesirable and almost impossible. It may be assumed, 
therefore, that the recent agitations from some minority sections are not unconnected with the mismanagement of our resources, particularly those resources emanating from the minority areas and the apparent competition among the majority groups. ${ }^{34}$

Germane to this analysis is the assumption that those agitating for the creation of ethnic states are possibly doing so because the efforts, hopes and desires of their collectivities are baffled and thwarted in Nigeria's contemporary political matrix. Probably, when these frustrations and anxieties are addressed, their quest for ethnic states might be mollified. But the political depth of the attachment to ethnonationalism in the politics of the republic is so profound that it must not be taken for granted. How might the question and complexity of ethnonationalism in Nigeria's politics be tackled, in order to mitigate its noncentripetal dimensions? This will be the central focus of the proceeding discussion.

\section{Possible Solutions}

Providing solutions to the centrifugal and endemic problems of ethnic politics in the struggle for power and the authoritative allocation of values in Nigeria is problematic. The continued allure of ethnonationalism issues form the sociopolitical rewards of one's attachment to it. This is so because the success of ethnic nationalism offers the ethnic nationalist easy access to mobilize the group in the struggle for the national distribution of goods and services. ${ }^{35}$ This has been the situation before and after independence. The result was that even some of the founding fathers of the country (Abubakar, Zik, and Awolowo) sought solace in their ethnic regions (north, east and west). Indeed, Richard Sklar has contended that, in the struggle for political supremacy and the control of amenities in the First Republic, the "regional party leaders operated highly effective systems of patronage dispensing jobs, contracts, commercial loans, ... and scholarships. Young people in all parts of the country were pressured in various ways to support the regional government parties. ... Opinions followed interest, and many young adults furthered their careers by adopting regionalist principles and tribalist ideologies." 36

Whereas solutions to the problems of ethnonationalism in Nigerian politics are numerous and sometimes contradictory, I will briefly examine four feasible solutions in this essay. These are the constitution, the state, political culture and education.

One of the raisons d'être of the Abacha Conference is the writing of a new constitution, which will, among other factors, resolve the political antinomies rendering the Nigerian polity ungovernable. The 1979 constitution, which suggested ways for creating ethnic harmony, was a fundamental step in the direction of providing a solution to the ethnic problems in Nigeria. For instance, Art. 14 (3) of the 1979 constitution states that: "The composition of the Government of the Federation or any of its agencies and the conduct of its affairs shall be carried out in such manner as to reflect the federal character of Nigeria and the need to promote national unity, and also to command national 
loyalty, thereby ensuring that there shall be no predominance of persons from a few States or from a few ethnic or other sectional groups in that government or in any of its agencies." 37 This provision should remain intact in any future politico-constitutional paradigm or framework. Indeed, it is a sine qua non for the furtherance of ethnic harmony in the republic, because it recognizes the significance of every ethnic group in the ethnic mosaic that is Nigeria.

Second, the recognition of Nigeria's ethnic "melting pot" could be promoted by realizing and acknowledging the supremacy of the state as the agglutinating mechanism of the various ethnic cleavages. The assumption is that the state plays the role of assuaging the conflicting interests of the ethnic groups, which could further stability. But what is a state? According to Couloumbis and Wolfe, a state is a "political unit defined in terms of territory, population, and autonomous government that exercises effective control of the territory and its inhabitants regardless of their ethnic homogeneity or heterogeneity."38 In the Nigerian case the question has always been the extent to which ethnonationalists have declared their allegiance to the autonomous government. In truth, some minority ethnic groups have sought to withhold their allegiance to the central government because their needs have been ignored. It was Plato who asserted in the Republic that: "Our aim in founding the State was not the disproportionate happiness of any one class [or ethnic group], but the greatest happiness of the whole; we thought that in a state which is ordered with a view to the good of the whole be most likely to find justice and the ill-ordered state, injustice." 39

Pressed to wax philosophically, many Nigerianists, especially the political observers, may agree that the three major ethnic groups (Hausa-Fulani, Ibo and Yoruba) have dominated the political and economic spheres of Nigeria to the chagrin or disappointment of the minority groups. This condition and perception only furthers the attraction to ethnonationalism, especially among the minority groups who suffer from political and economic marginalization. To combat their alienation, the Nigerian state must strive for an equitable distribution of the national resources and wealth. In short, it must promulgate policies aimed at political and economic enfranchisement of all Nigerians.

Third, as Claude Ake contended, the establishment of a political culture that could command national legitimacy is essential for successful governing in Nigeria. In fact, he has argued that the basic problem of unity in Nigeria has two dimensions: 1 . how to elicit deference and devotion to the claims of the state from its subjects (implying the conversion of ethnic nationalism to nationstate nationalism); and 2. how to increase normative consensus governing political behavior among members of the political system. This means that the problem of national unity entails developing a political culture and urging the people's commitment to it. ${ }^{40}$ So, the need to devise an efficacious political culture for the republic is imperative.

Fourth, it is a given that solutions to Nigeria's myriad political problems from the right and left of the ideological spectrum abound. But it is one thing to prescribe solutions to a problem and quite another to implement them. The 
implementation issue becomes more problematic if aimed at those who have been "corrupted" by the system. To this end, it has been contended elsewhere that in order to combat the country's future political malaise and disarticulation, the republic should embark on a political education of its "uncorrupted" youth. Such an education should emphasize the following dimensions: 1. Politics is a variable sum game; 2. National interests supersede individual, parochial, provincial and regional interests; 3. Political parties represent national interests, not just party members interests; 4 . The respect for human rights; and 5. Freedom of expression. ${ }^{41}$

The process of tackling ethnic concerns in Nigerian politics is not an easy one, because of the sensitivity of the subject matter. The preceding discussion was intended to contribute to the debate as the Abacha administration confronts the onerous task of designing a political framework that could resolve the politico-social and religio-economic antinomies inherent in the Nigerian polity. Nigerians will never peel off their ethnic identity; nor is it necessary to do so. However, the threat of disintegration into macro and micro ethnic states, à la EMIROAF, could be averted if Nigerians, regardless of geo-ethnic origin, are provided equality of opportunity, justice, and fair play.

\section{NO'TES}

1 N. Kofele-Kale, Tribesmen and Patriots: Political Culture in a Polyethnic African State (Washington, DC: University Press of America, 1981), p. 7. See for example, Article 2 (1), of the Constitution of Oron Development Union of Washington, DC., USA. This article states that the objective of the Union is "to promote love, unity, understanding, welfare and good relationships among Oron citizens in the Washington metropolitan area as well as the United States of America." Nowhere in the constitution was it stated that the group would also strive to further unity among other Nigerian organizations in the area. Arguably, the proliferation of similar groups in North America, Europe and Nigeria itself does not enhance Nigerian unity.

2 Nduka Otiono, "No Regime should take the people for a ride," Sentinel, Vol. 1, No. 16 (June $13,1994)$, p. 12.

3 Alvin Rabushka and Kenneth A. Shepsle, Politics in Plural Societies: A Theory of Democratic Instability (Columbus, OH: Charles E. Merrill Publishing Company, 1972), p. 66.

4 See "The Great Debate: Troubled Nigeria prepares to examine itself at a constitutional conference," West Africa (February 14-20, 1994), p. 251.

5 Ibid.

6 See "One Viewpoint," West Africa (February 14-20, 1994), pp. 255-256.

7 Okwudiba Nnoli, Ethnic Politics in Nigeria (Enugu: Fourth Dimension Press, 1980), pp. 5-9.

8 Bernard E. Segal, "Ethnicity: Where the Present is the Past," in Raymond L. Hall (ed.), Ethnic Autonomy-Comparative Dynamics: The Americas, Europe and the Developing World (New York: Pergamon Press, 1979), p. 7.

9 R.N. Ismagilova, Ethnic Problems of the Tropical Africa: Can They Be Solved? (Moscow: Progress Publishers, 1978), p. 137.

10 Ibid.

11 Emmanuel Ike Udogu, "National Integration Attempts in Nigerian Politics 1979-1984," Canadian Review of Studies in Nationalism, Vol. XVII, No. 1-2 (1990), pp. 166-167.

12 Nnoli, op. cit., p. 9.

13 Ibid.

14 Arche Mafeje, "The Ideology of Tribalism," Journal of Modern African Studies, Vol. IX, No. 2 (1971), pp. 253-262. 
15 B. Magubane, "Pluralism and Conflict Situations in Africa: A New Look," African Social Research, Vol. VII, No. 2 (June 1969), p. 538.

16 Richard Sklar, "Political Science and Political Integration," Journal of Modern African Studies, Vol. V, No. 1 (1967), pp. 6-8.

17 Nnoli, op. cit., p. 11 .

18 Cited in James S. Coleman, Nigeria: Background to Nationalism (Berkeley and Los Angeles: University of California Press, 1958 ed.), pp. 193-194.

19 Udogu, op. cit., p. 159.

20 Ayeni Olugbenga, "Which way forward," West Africa (February 14-20, 1994), p. 255. See also Coleman, op. cit., p. 320; West African Pilot (November 3, 1948).

21 Obafemi Awolowo, Path to Nigerian Freedom (London: Faber and Faber, Ltd., 1947), pp. 47-48; See Coleman, op. cit., p. 320; Olugbenga, op. cit., p. 255.

22 Olatunde J. B. Ojo, "The Impact of Personality and Ethnicity on the Nigerian Elections of 1979," Africa Today, vol. 28, No. 1 (June 1, 1981), pp. 47-58.

23 See Victor A. Olorunsola (ed.), The Politics of Cultural Subnationalism in Africa New York: Doubleday and Company, Inc., 1972), pp. 5-43; Larry Diamond, "Nigeria in Search of Democracy," Foreign Affairs, Vol. 62, No. 4 (Spring, 1984), pp. 905-927; Crawford Young, "Comparative Claims to Political Sovereignty: Biafra, Katanga, Eritrea," in Donald Rothchild and Victor Olorunsola (eds.), State Versus Ethnic Claims: African Policy Dilemmas (Boulder CO: Westview Press, 1983), pp. 204-211; The Politics of Cultural Pluralism (Madison: University of Wisconsin Press, 1979), pp. 274-281.

24 Walker Connor, "The Politics of Ethnonationalism," Journal of International Affairs, Vol. 27, No. 1 (1973), pp. 1-23.

25 See "One Viewpoint," op. cit., p. 255.

26 Ibid.

27 Ibid.

28 Ibid., p. 256.

29 Arthur A. Nwankwo and Samuel U. Ifejika, Biafra: The Making of a Nation (New York: Praeger Publishers, 1970), p. 304. Indeed, in February 1966, Isaac Boro declared the secession of the Delta area from Nigeria. A somewhat similar concern has been articulated by Ken Soro Wiwa, a spokesman for the Ogoni ethnic group in the Rivers State. Indeed, he has consistently condemned the economic exploitation and ecological devastation of the Ogoni land by the oil companies with little or inadequate compensation from the federal government to the people of this oil-rich entity. See Bola Olowa, "The Constitutional conference: Ethnic groups are fighting regional nations for a slice of the electoral cake," West Africa (March 14-20, 1994), p. 438 .

30 Olowa, op. cit., p. 438.

31 Udogu, op. cit., pp. 157-173. See also Larry Diamond, "A Tarnished Victory for the NPN," Africa Report, Vol. 28, No. 6 (November-December, 1983), pp. 18-22; ojo, op. cit., pp. 47-58.

32 Colin Legum, "Tribal Survival in the Modern African Political System," Journal of Asian and African Studies, Vol. 5, No. 1-2, (January-April, 1979), p. 102.

33 See James S. Coleman, in Gabriel Almond and James S. Coleman (eds.), The Politics of Developing Areas (Princeton: Princeton University Press, 1960), p. 259.

34 See "The Kaduna Caucus," West Africa (February 14-20, 1994), p. 252. Olusegun Obasanjo also noted, "I have always maintained that I would be more diminished as a citizen of Oduduwa Republic than as a citizen of Nigeria. I believe that those who might seek solace in the Republic of Dan Fodio would be equally diminished. The same goes to those who sought solace in the Republic of Biafra. But, more importantly, as experience in other parts of the world shows we would be further impoverished if we distintegrate, as we would have to spend an increasing part of whatever resources we have on arms and armament, if only to assuage the consequent feelings of insecurity and suspicion."

35 Udogu, op. cit., p. 159.

36 Richard Sklar, "Nigeria Politics in Perspective," Government and Opposition, Vol. 2, No. 4 (1967), pp. 524-539. 
37 See The Constitution of the Federal Republic of Nigeria (Lagos: Daily Times Publication, 1979), p. 16.

38 Theodore A. Couloumbis and James H. Wolfe, Introduction to International Relations: Power and 7ustice 4th ed. (Englewood Cliffs, NJ.: Prentice Hall, 1990), p. 60. See also Claude Ake, "the State in Contemporary Africa," and "The Nigerian State" antinomies of a periphery formation," in Claude Ake (ed.), Political Economy of Nigeria (London: Longman Group Limited, 1985), pp. 1-7, and 9-32.

39 See T. D. Waldon, State and Morale: A Study in Political Conflicts (London: John Murray, 1962), p. 37; Eghosa Osaghae, "Social Mobilization as a Political Myth in Africa," Africa Quarterly, Vol. 30, Nos. 3-4 (1990), p. 8.

40 Claude Ake, The Theory of Political Integration (Homewood, IL: The Dorsey Press, 1967), p. 1.

41 E. Ike Udogu, "In Search of Political Stability and Survival: Toward Nigeria's Third Republic," Scandinavian Journal of Development Alternatives, Vol. XI, No. 2 \& 4 (SeptemberDecember, 1992), p. 17. 